\title{
DETERMINATION OF MINIMUM INSULATION RESISTANCE REQUIREMENTS FOR OUTER REFLECTOR GAS TEMPERATURE THERMOCOUPLES
}

\author{
Prepared By:

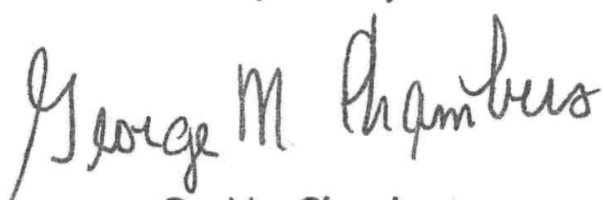 \\ G. M. Chambers \\ Sensor Application Engineering
}

Approved By:

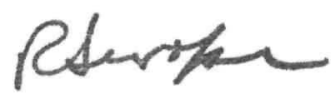

R. R. Swope, Supervisor

Sensor Application Engineering

Instrumentation and Control

\section{Morice}

PORTIONS OF THIS REPORT ARE ILLEGIBLE "H

June 11, 1965

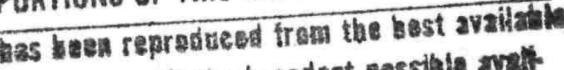

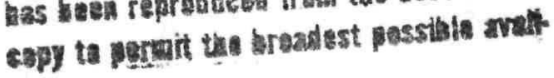
Ruts.

This report wotice

This report was prepared as an account of work sponsored by the United States Government. Neither the United States nor the United States Research and Development Administrates Energy their employees, nor Administration, nor any of their employees, nor any of their contractors, subcontractors, or their employees, makes any warranty, express or implied, or assumes any legal liability or responsibility for the accuracy, completeness or usefulness of any information, apparatus, product or process disclosed, or represents that its use would not infringe privately owned rights. 


\section{DISCLAIMER}

This report was prepared as an account of work sponsored by an agency of the United States Government. Neither the United States Government nor any agency Thereof, nor any of their employees, makes any warranty, express or implied, or assumes any legal liability or responsibility for the accuracy, completeness, or usefulness of any information, apparatus, product, or process disclosed, or represents that its use would not infringe privately owned rights. Reference herein to any specific commercial product, process, or service by trade name, trademark, manufacturer, or otherwise does not necessarily constitute or imply its endorsement, recommendation, or favoring by the United States Government or any agency thereof. The views and opinions of authors expressed herein do not necessarily state or reflect those of the United States Government or any agency thereof. 


\section{DISCLAIMER}

Portions of this document may be illegible in electronic image products. Images are produced from the best available original document. 


\section{DETERMINATION OF MINIMUM INSULATION RESISTANCE REQUIREMENTS FOR OUTER REFLECTOR GAS TEMPERATURE THERMOCOUPLES}

\section{SCOPE:}

This report describes the analysis performed in determining the lowest permissable insulation resistance for the exposed junction copper/constantan shermocouples required to measure outer reflector drum annulius, drum vane and beryllium exir gas temperafures.

INTRODUCTION:

On June 4, 1965, a meeting* was held by representatives of Sensor Application Engineering, Reactor Assembly, Quality Control and Reliability and Quality Assurance to determine an investigation procedure for checking the possible cause of low $I_{0} R_{0}$ (insulation resistance) of the NRX/EST outer reflector expased junction thermocouples. The insulation resistance of these six thermocouples, WANL part number $945 \mathrm{C} 906 \mathrm{HOl}$, had decreased below the 50 megohms point which is specified as being the lowest acceptable limit. Since the NRX/EST outer reflector has been assembled and the instrumentation seal block brazed these themocouples cannot be removed and baked out to improve the insulation resistance.

It was agreed at the June 4 meeting, that no direct physical action should be taken in the area around the fragile exposed junction unless the insulation resistance reaches a value so low that it is detrimental to test data.

It should be pointed out that al though the 50 megohm value is specified as the lowest acceptable limit for the exposed junction thermocouple, ceriain themocouples could have a lower than 50 megohm insulation resistance and still provide valid data. The minimum limit is basically dependent on thermocouple type, location in the core and $I_{0} R_{0}$ distribution in the thermocouple. It is impractical to specify various $l_{0} R_{0}$ requirements for each thermocouple since any one type of thermocouple may be installed at various locations in the core. The $\mathbf{5 0}$ megohms limit was chosen as standard because it appears sufficient for all types of thermocouples and is a practical value to obtain。

* IC-4638 (ISFS-1022), "Investigation Procedure of Low Insulation Resistance of NRX/EST Outer Reflector Exposed Junction Thermocouple per FDDR No. 2608, " dated June 4, 1965. 
1. R。 DETERMINATION:

A detailed look into the effects of insulation resistance $\left(l_{0} R_{0}\right)$ upon the thermocouple operation shows that this is a multiple and complex area in which different phases must be considered. For example, consider the possible thermoelectric effect between the copper or constantan conductors and the stainless sheath as shown in Figure 1 below.

Exposed Junction

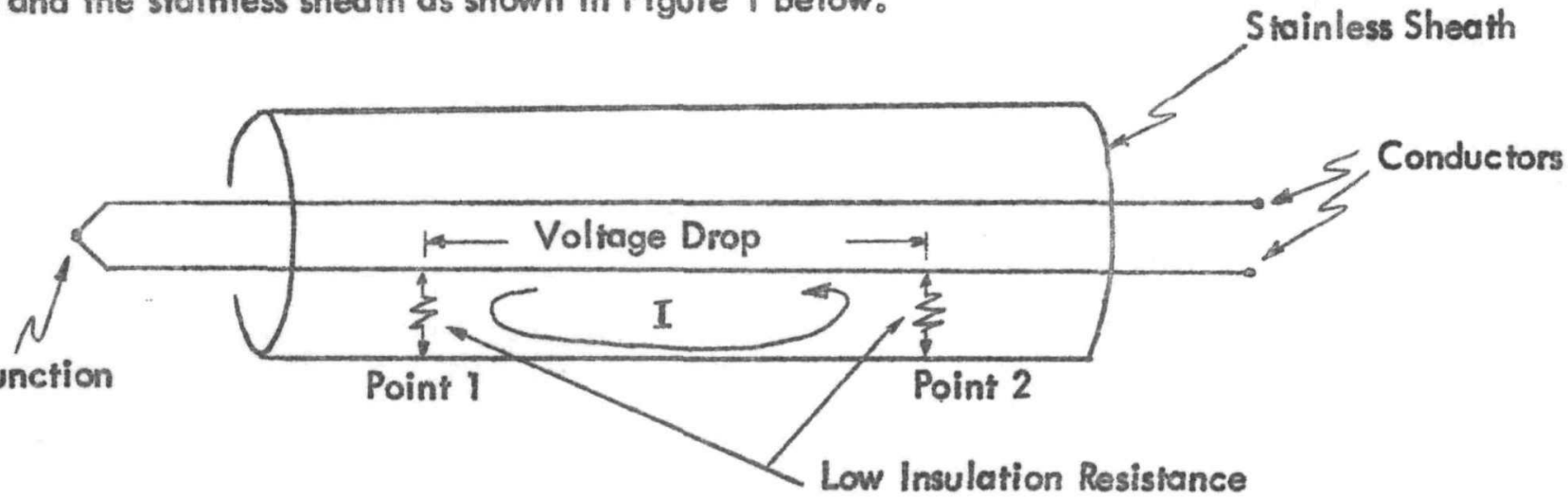

Figure 1

It can be seen that a volfage drop could exist due to thermoelectric effect between the thermocouple conductor and the stainless sheath. This would either add to or buck the actual output, depending mainly on the $I_{0} R_{0}$ and $\Delta$ temperature, af points $I$ and 2 and the conductor material. To be able to actually predict this effect would be very difficult since the $I_{0} R_{0}$ at various points inside the sheath cannot be directly measured. For practical purposes, effects of this nature will be considered negligible, however, it should be kept in mind that these effects are possible and could cause an error.

Neglecting any side effects, the basic equivalent DC circuit for the thermocouple is shown in Figure 2 below.

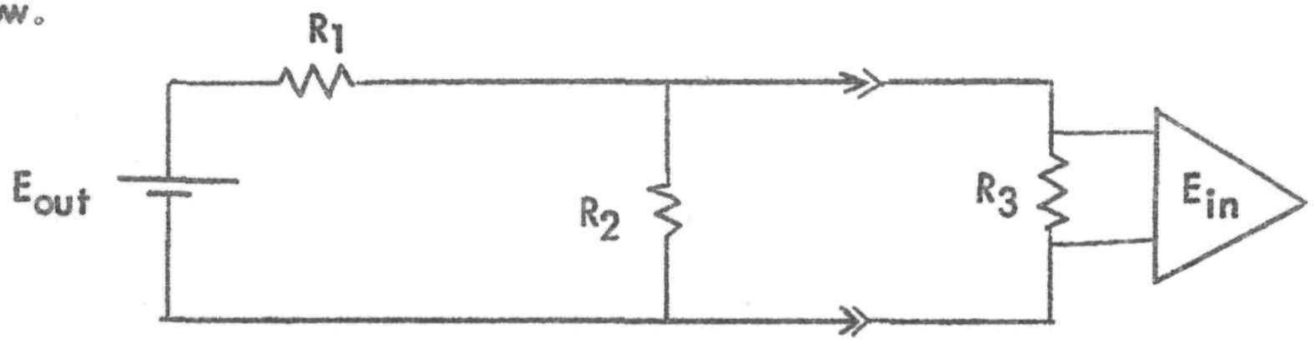

Figure 2

where: $E_{\text {out }}=$ thermocouple thermcelectric output.

$E_{\text {in }}=$ voltage input to the amplifier. 
$R_{1}=$ equivalent thermocouple conductor resistance.

$R_{2}$ = insulation resistance.

$R_{3}=$ amplifier input impedance.

It can be seen that when the insulation resistance $\left(R_{2}\right)$ is excluded, the circuit is basically a voltage divider with the input to the amplifier being $E_{\text {out }} \times \frac{R_{3}}{R_{1}+R_{3}}$. When $R_{1}$ is much less than $R_{3}$, practically all the thermocouple output is dropped across $R_{3}$ and fed to the amplifier. When the insulation resistance is included, it parallels the input impedance and produces an equivalent resistance equal to the product over the sum of $R_{2}$ and $R_{3}$. It can be seen that if the insulation resistance decreases, this equivalent resistance will decrease and less voltage will reach the amplifier.

The relationship between the insulation resistance and percent of thermocouple output reaching the amplifier is as follows: (Refer to Figure 2)

1. Assume $R_{1}=50$ ohms (This is typical for the conductor resistances of the subject thermocouples.)

$R_{2}=$ Variable (The insulation resistance that is measured on the subject thermocouples is not actually measured between conductors as shown by $R_{2}$ in Figure 2。 In order for a measurement to be made between conductors, the junction would hove to be opened which is impractical. The actual measurement is made befween conductors and the metal sheath. This was found to be a good representative of the conductor to conductor insulation.)

$R_{3}=60,000$ ohms (This is typical for the amplifiers.)

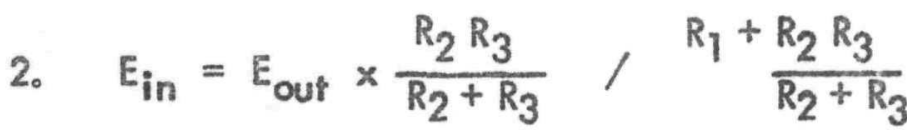

3. $E_{\text {in }}=E_{\text {out }} \times \frac{R_{2} R_{3}}{R_{2}+R_{3}} \times \frac{R_{2}+R_{3}}{R_{1} R_{2}+R_{1} R_{3}+R_{2} R_{3}}$ 


$$
\begin{aligned}
& \text { 4. } E_{\text {in }}=E_{\text {out }} \times \frac{R_{2} R_{3}}{R_{2}\left(R_{1}+R_{3}\right)+\left(R_{1} R_{3}\right)} \\
& \text { 5. \% } E_{\text {out reaching }} E_{\text {in }}=\frac{E_{\text {in }}}{E_{\text {out }}} \times 100 \\
& \text { 6. } \% E_{\text {out reaching }} E_{\text {in }}=\frac{E_{\text {out }} \times R_{2} R_{3}}{R_{2}\left(R_{1}+R_{3}\right)+\left(R_{1} R_{3}\right)} \times \frac{1}{E_{\text {out }}} \times 100 \\
& \text { 7. } \% E_{\text {out reaching }} E_{\text {in }}=\frac{\left(60 \times 10^{3}\right)\left(R_{2}\right)}{R_{2}\left(60.05 \times 10^{3}\right)+3 \times 10^{6}} \times 100
\end{aligned}
$$

Figure 3 graphically shows the relationship between the insulation resistance and the percent of thermocouple output reaching the amplifier for the previous assumed criteria. It should be noted that for other types of thermocouples such as chromel/alumel, the conductor resistance $\left(R_{T}\right)$ is larger which would cause the effects of a decreasing $I_{0} R_{0}$, to become more pronounced. From Figure 3 it oppears that below 500K ohms the percentage of output to the amplifier storts to decrease more rapidly.

Refering to Figure 3, with an $I_{0} R_{0}$ of $500 \mathrm{~K}$ ohms $\mathrm{s}_{p} 99.906 \%$ of the thermocouple output will reach the amplifier. What this corresponds to in semperature error can be determined from Figure 4 which shows the actual calibration information on the subject themocouples. For the lower temperature range shown in Figure 5, there is a relatively small degree of thermocouple voltage change in respect to a femperature change. In this range any reduction in insulation resistance will produce a greater percent error than in the higher more linear temperafure range. For example, an insulation resistance of 500K ohms could produce the following error at a temperature of $35^{\circ} \mathrm{R}$ :

1. $-6.202 \mathrm{MV} \times 99.906 \%=-6.196 \mathrm{MV}$ to the amplifier。

2. $-6.196 \mathrm{MV}$ corresponds to $38^{\circ} \mathrm{R}$ on the curve in Figure 5 (Group IV)。

3. Therefore an error of $+3{ }^{*} \mathrm{R}$ or approximately $0.5 \%$ of full ronge. As the remperafure of the subject themocouples increases, the error decreases for a constant $I_{0} R_{\text {o }}$ value. This is mainly due to a larger thermocouple voltage change taking place in respect to temperature change. 
For the same insulation resistance (500K ohms) but with a higher temperature range, the following error could be produced: (Taking $300^{\circ} \mathrm{R}$ for example)

1. $-3.559 \mathrm{MV} \times 99.906 \%=-3.555 \mathrm{MV}$ to the amplifier。

2. This corresponds to a temperature of $300.28^{\circ} R$.

3. Therefore an error of $+0.28^{2} \mathrm{R}$ or $0.045 \%$ of full runge was produced.

The following rable shows the possible error produced af low and relatively high temperatures for various insulation resistance values:

\begin{tabular}{|c|c|c|c|c|}
\hline \multirow[b]{2}{*}{ Temperafure } & \multicolumn{4}{|c|}{ Degrees Erros/Percent Error of Full Range } \\
\hline & $I_{0} R_{0}=50$ megohms & $I_{0} R_{0}=1 \mathrm{megohm}$ & $I_{0} R_{0}=500 \mathrm{~K}$ ohms & $I_{0} R_{0}=I \mathrm{~K}$ ohms \\
\hline $35^{\circ} \mathrm{R}$ & $+2^{\circ} \mathrm{R} / \mathrm{O}, 31 \%$ & $+3^{\circ} \mathrm{R} / \mathrm{O}_{0} 48 \%$ & $+3^{\circ} \mathrm{R} / 0,48 \%$ & $+55^{\circ} R / 8.85 \%$ \\
\hline $300^{\circ} \mathrm{R}$ & $+0.26^{\circ} \mathrm{R} / \mathrm{O} .041 \%$ & $+0.26^{\circ} \mathrm{R} / 0.041 \%$ & $+0.28^{\circ} \mathrm{R} / .045 \%$ & $+14.5^{\circ} \mathrm{R} / 2.33 \%$ \\
\hline
\end{tabular}

"Minimum amount permissable as specified by controt process specification Table I

It appears that with ambient conditions, the subject thermocouples could operate throughout most of its range without producing significant error with a minimum I。 $R_{\circ}$ of $500 \mathrm{~K}$ ohms. With a decrease in temperature from ambienty. the resistance of the thermocouple conductors decreases which lessens the I. R。 effect at a given value. Available Plum Brook and GTR reports indicate that radiation olso has an effect on the insulation resistance. * If appears that the general frend of the insulation resistance during a reactor run was an initial decrease with reacfor startup which generally leveled off during the run and then increased after recctor shutdown. If the 500K ohm I. R. region (which appears to be satisfactory for ambient conditions) were to drop during irradiation, a significant error could result. Therefore, it appears necessary to increase the ambient. requirement to 1 megohm minimum to allow as a safety factor for irradiation decrease.

*Refo:

WANL-TME-638, "Summary of NERVA Instrumentation Review Meeting at WANL, December $17-19,1963$, " dated $1 / 2 / 64$ 。

WANL-TME-691, "NRX-A Candidate Diagnostic Transducers Irradiated at Plum Brook Reactor Facility, Cycles 4 (PB No。 IW), " dated 4/6/64。 


\section{CONCLUSIONS AND RECOMMENDATIONS:}

Based on this analysis, an insulation resistance of one megohm minimum is permissable for the subject thermocouples. This is assuming that other thermoelectric effects (such as those between the copper-constantan and stainless steel sheath) are negligible and also that irradiation will not cause a decrease in I. $R_{0}$. less than 500K ohms. It is recommended that actual fests on the effects of insulation resistance on sensor performance be continued in respect to the irradiation, remperature, and other related effects。 


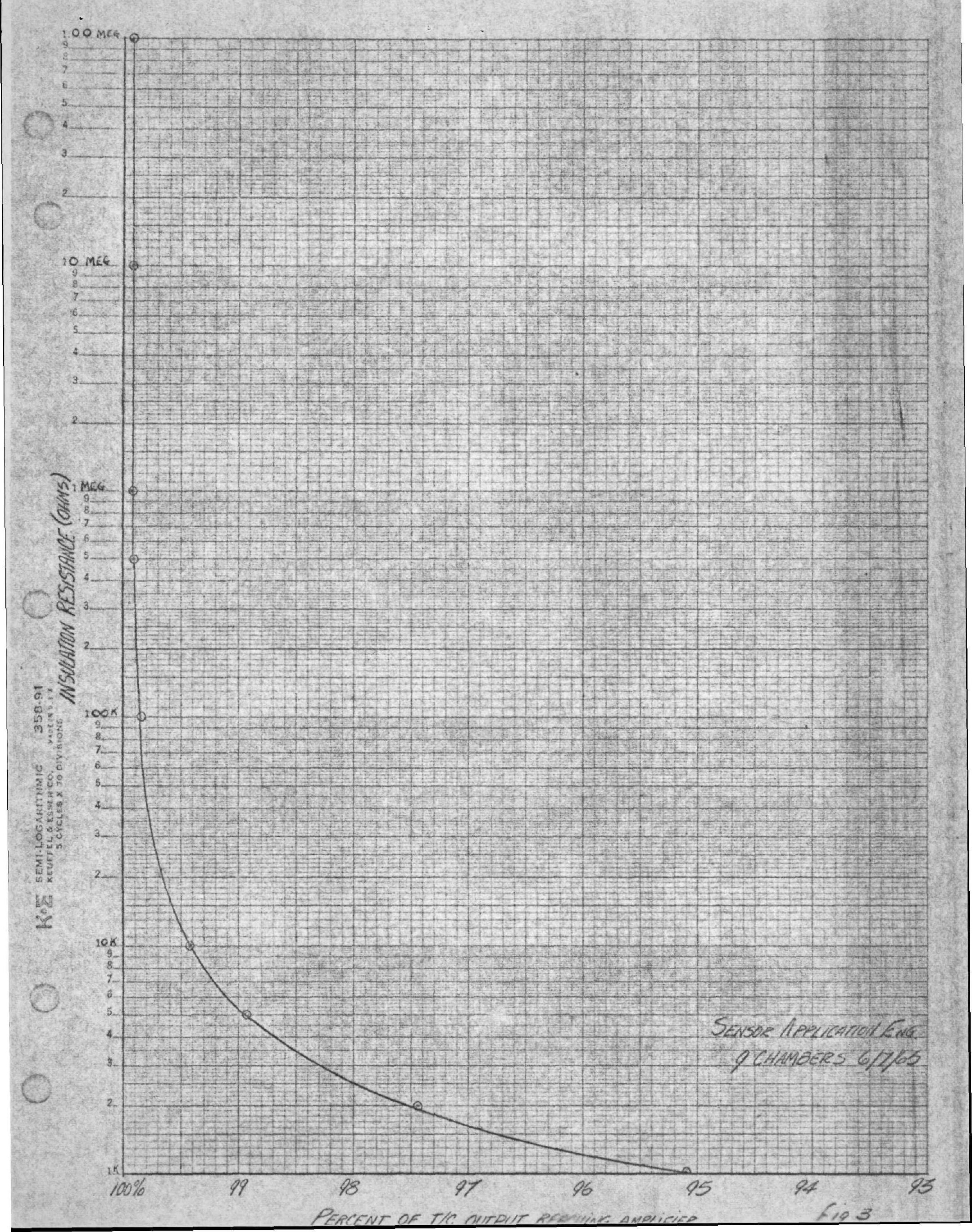




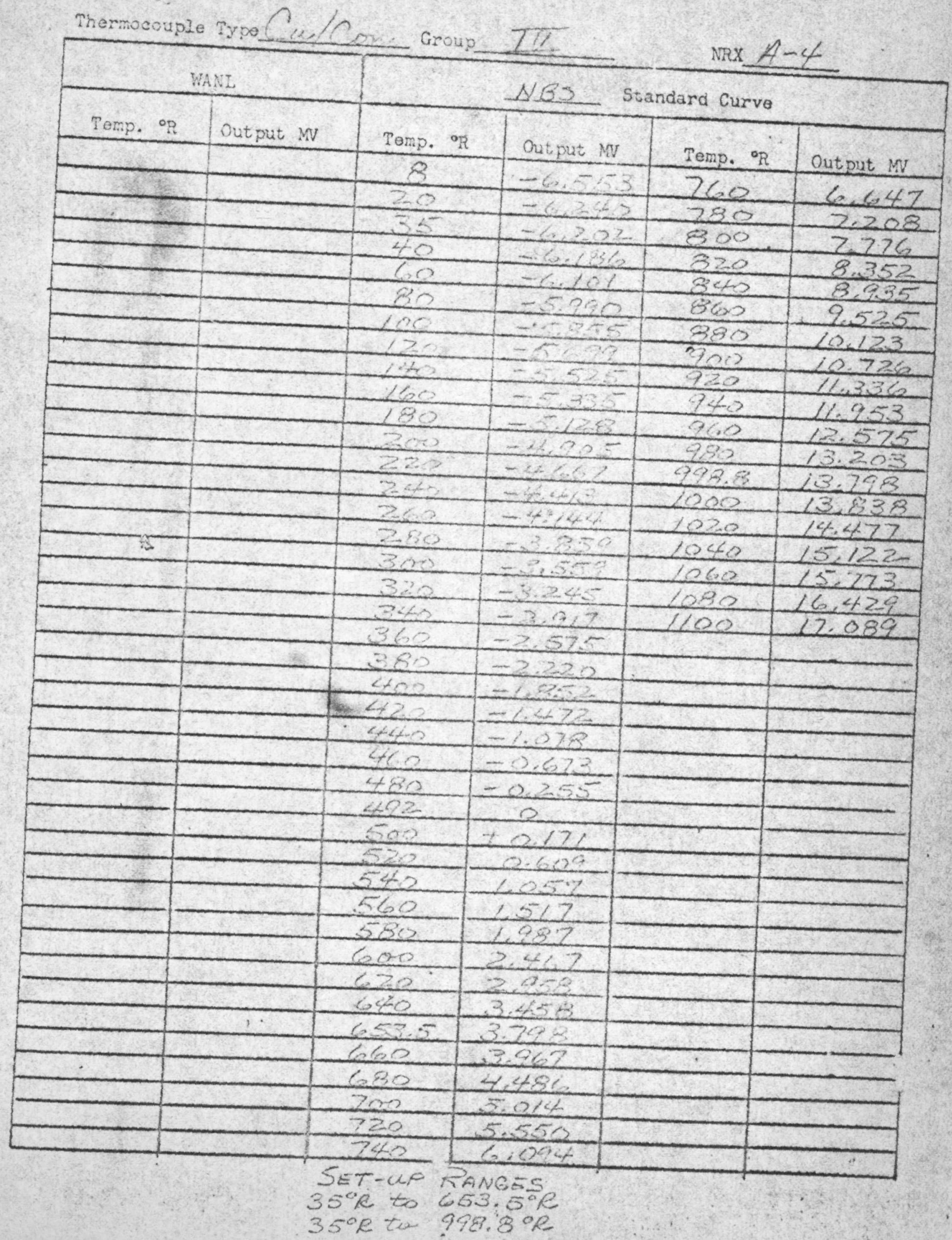




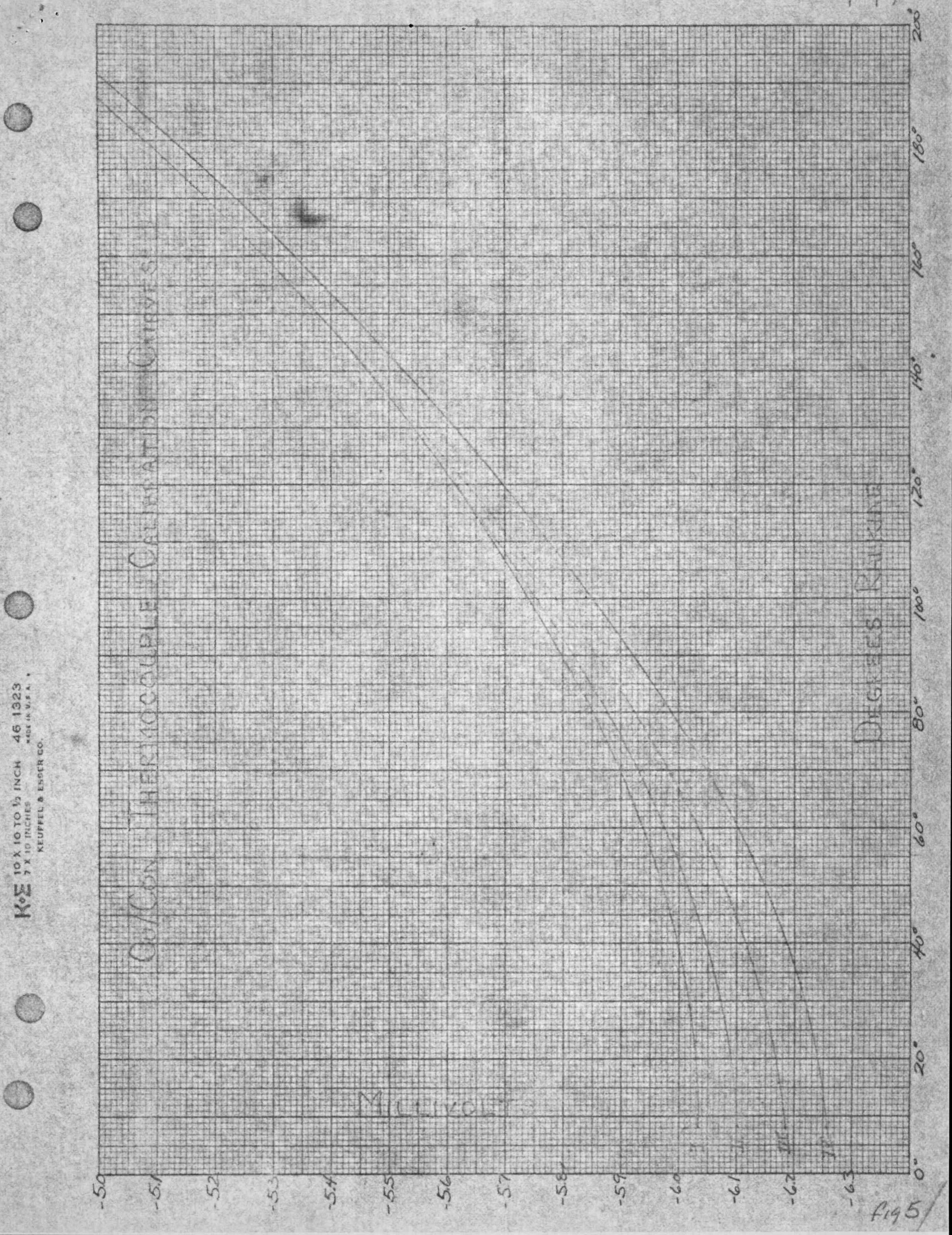

